\title{
PLANTING SYSTEM EFFECTS ON INTERCROPPING OF GARDENPEA AND SORGHUM
}

\author{
A.A. Begum* ${ }^{1}$ M.A.K. Mian ${ }^{1}$, S.M.A.H.M. Kamal ${ }^{2}$, M.R.Karim ${ }^{1}$, \\ R.R.Saha ${ }^{3}$ and M.A. Hossain ${ }^{4}$ \\ ${ }^{1}$ Agronomy Division, BARI, Gazipur-1701 \\ ${ }^{2}$ RARS, Burirhat, Rangpur, ${ }^{3}$ Oilseed Research Center-1701 \\ ${ }^{4}$ OFRD, BARI, Gazipur-1701 \\ *Corresponding E-mail: luckyshamol6869@gmail.com
}

(Received: 30 September, 2020, Accepted: 20 October, 2020)

Keywords: Intercropping, sorghum, gardenpea, light availability, equivalent yield, BCR

\begin{abstract}
The field experiment was conducted at Agronomy Research Field, Joydebpur and RARS, Burirhat, Rangpur, BARI during Rabi season of 2018-2019 and 2019-2020 to find out suitable combination of sorghum and gardenpea intercropping for higher productivity and monetary advantage. Treatments included in the experiment were: $\mathrm{T}_{1}=$ Sorghum normal row $(\mathrm{SNR})+1$ row gardenpea $(\mathrm{GP}), \mathrm{T}_{2}=\mathrm{SNR}+2$ rows $\mathrm{GP}, \mathrm{T}_{3}=$ Sorghum paired row $(\mathrm{SPR})+2$ rows GP, $\mathrm{T}_{4}=\mathrm{SPR}+3$ rows GP, $\mathrm{T}_{5}=\mathrm{SPR}+4$ rows GP, $\mathrm{T}_{6}=$ Sole sorghum $(60 \mathrm{~cm} \times 10 \mathrm{~cm})$ and $\mathrm{T}_{7}=$ Sole $\mathrm{GP}(30 \mathrm{~cm} \times 10 \mathrm{~cm})$. Light availability on gardenpea decreased with the increase of shade produced by sorghum canopy over the time up to 60 DAS. The lowest light availability on gardenpea was observed in $T_{2}$ treatment and the highest was observed in sole gardenpea $\left(\mathrm{T}_{7}\right)$ followed by $\mathrm{T}_{3}$ treatment in both the years. The maximum grain yield of sorghum was observed in $\mathrm{T}_{6}$ and it was decreased (6-10\% in 2018-2019 and 1-12\% in 2019-2020) at Joydebpur and (5-11\% in 2018-2019 and 6-14\% in 2019-2020) at Burirhat. The highest sorghum equivalent yield (SEY) of $10.93 \mathrm{t} \mathrm{ha}^{-1}$ in 2018-2019 and $12.02 \mathrm{t} \mathrm{ha}^{-1}$ in 2019-2020 at Joydebpur and $12.06 \mathrm{t} \mathrm{ha}^{-1}$ in 2018-2019 and $11.77 \mathrm{t} \mathrm{ha}^{-1}$ in 2019-2020 at Burirhat and also the highest land equivalent ratio (LER) of 1.77 in 2018-2019 and 1.93 in 2019-2020 at Joydebpur and 1.79 in 2018-2019 and 1.81 in 2019-2020 at Burirhatwere observed in $\mathrm{T}_{5}$ treatment. The highest gross margin of Tk.146600 ha ${ }^{-1}$ in 2018-2019 and Tk.168400 ha ${ }^{-1}$ in 2019-2020 at Joydebpur and Tk. $169200 \mathrm{ha}^{-1}$ in 2018-2019 and Tk.163400 ha ${ }^{-1}$ in 2019-2020 at Burirhat and also the benefit cost ratio (BCR) of 3.04 in 2018-2019 and 3.34 in 2019-2020 at Joydebpur and 3.35 in 2018-2019 and 3.27 in 2019-2020 at Burirhat were also found in the same treatment. The results revealed that sorghum paired row +4 rows gardenpea might be agronomically feasible and economically profitable for sorghum + gardenpea intercropping system at Joydebpur and Burirhat region.
\end{abstract}

\section{Introduction}

Intercropping is an important tool for getting higher productivity per unit area of land (Mahfuza et al., 2012). Higher productivity from intercropping depends on judicious choice of component crops, suitable planting system or proportion of component crops (Islam et al., 2006). Sorghum is an unbranched and erect cereal crop grown with a wide spacing. Several short duration and short stature vegetable like garden pea may be grown in association with sorghum. Sorghum grain is as nutritious as other cereal grains; contains about $11 \%$ water, $340 \mathrm{k}$.cal of energy, $11.6 \%$ protein, $73 \%$ carbohydrate and 3\% fat by weight (Thimmaiah, 2002; Taylor et al., 2006; Yan et al., 2012). It is used as food, feed, fodder and fuel. Sorghum's health benefits include more antioxidants, high protein, fiber and gluten free which make it a perfect dietary grain for all people, especially celiac patients. Certain sorghum 
varieties are more easily digestible. On a field basis, sorghum yields have exceeded $11 \mathrm{t} \mathrm{ha}{ }^{-1}$ with above average yields ranging from $7-9 \mathrm{t} \mathrm{ha}^{-1}$ where moisture is not a limiting factor.

Gardenpea is a very popular vegetable with rich in different nutrients. It contains about $68 \mathrm{~g}$ water, 127 k.cal of energy, $7.4 \mathrm{~g}$ protein, $24 \mathrm{~g}$ carbohydrate and $26 \mathrm{~g}$ calcium per 100 grams edible portion. Generally legumes in association with non-legumes helps not only in utilization of the nitrogen being fixed in the current growing season, but also helps in residual nutrients build up of the soil (Kakraliya et al., 2018). Legumes enrich the soil with $\mathrm{N}$ and thus facilitate a better environment to subsequent crops for better growth and productivity (Meena et al., 2015). Legume cultivation releases up to seven times less GHGs per unit area than non-legume crops. Legumes allow the sequestration of carbon (1.42 $\mathrm{Mg} \mathrm{C} \mathrm{ha}{ }^{-1}$ year $^{-1}$ ) in soils and induce the conservation of fossil energy inputs in the system (Kakraliya et al., 2018).

Farmers in the developing countries often demand for quick return from their crops, so they can get quick return by growing short duration vegetable crops with long duration crop like maize, sorghum etc. However, suitable intercrops, local food habit and market demands are important factors for getting higher benefit from intercropping. However, findings on profitability of sorghum + gardenpea intercropping under different planting systems are meagre in Bangladesh. So, this experiment was conducted to find out suitable intercrop combination and planting system of sorghum and gardenpea intercropping for higher productivity and economic return.

\section{Materials and Methods}

The field experiment was conducted at the Agronomy Research Field, Joydebpur, Gazipur and RARS, Burirhat, Rangpur, BARI during Rabi season of 2018-2019 and 2019-2020. The soil was silty clay in texture at Joydebpur (AEZ-28) and sandy loam at Burirhat, Rangpur (AEZ-3). Treatments included in the experiment were: $\mathrm{T}_{1}=$ Sorghum normal row $(\mathrm{SNR})+1$ row gardenpea $(\mathrm{GP}), \mathrm{T}_{2}=\mathrm{SNR}+2$ rows GP, $\mathrm{T}_{3}=$ Sorghum paired row $(\mathrm{SPR})+2$ rows GP, $\mathrm{T}_{4}=\mathrm{SPR}+3$ rows GP, $\mathrm{T}_{5}=\mathrm{SPR}+4$ rows GP, $\mathrm{T}_{6}=$ Sole sorghum $(60 \mathrm{~cm} \times 10 \mathrm{~cm})$ and $\mathrm{T}_{7}=$ Sole GP $(30 \mathrm{~cm} \times 10 \mathrm{~cm})$. The experiment was laid out in a randomized complete block design with three replications and the unit plot size was $4.8 \mathrm{~m} \times 5 \mathrm{~m}$ in both locations in both years. Local sorghum variety (BSL-20) and BARI Sorghum- 1 was used in $1^{\text {st }}$ and $2^{\text {nd }}$ year, respectively, and BARI Motorshuti-3 were used in the experiment for both locations in both years. Seeds of sorghum and gardenpea were sown on same day. In $1^{\text {st }}$ year, seeds were sown on 22 November 2018 at Joydebpur and 15 November 2018 at Burirhat and in $2^{\text {nd }}$ year, seeds were sown on 24 November 2019 at Joydebpur and 17 November 2019 at Burirhat. Seeds of both crops were treated with provax @ $3 \mathrm{~g} \mathrm{~kg}^{-1}$ of seed in both locations. Fertilizers were applied at the rate of 120-48-75-30-3$1 \mathrm{~kg} \mathrm{ha}^{-1}$ of N, P, K, S, Zn, B as urea, triple super phosphate (TSP), muriate of potash (MoP), gypsum, zinc sulphate and boric acid for sole maize and intercrop. One third of N, whole amount of TSP, MoP, gypsum, zinc sulphate and boric acid were applied as basal. Remaining 2/3 N was top dressed at 25 and 45 days after sowing (DAS) of sorghum. In intercrop, extra $\mathrm{N}\left(40 \mathrm{~kg} \mathrm{ha}^{-1}\right)$ was applied in 2 splits at 20 and 35 DAS to gardenpea. Sole gardenpea was fertilized at the rate of 46- 25-31-13-2.1 kg ha-1 of N, P, $\mathrm{K}, \mathrm{S}$ and $\mathrm{Zn}$ (FRG, 2018). One third of $\mathrm{N}$ and all other fertilizers were applied as basal. Rest $\mathrm{N}$ was applied in 2 splits at 20 and 35 DAS in both locations in both years. Light availability or Photosynthetically active radiation (PAR) was measured only at Joydebpur location by PAR Ceptometer (Model - LP-80, Accu PAR, Decagon, USA). The PAR was measured at 5-day intervals from 25 to 60 DAS at around 11:30 am to 13:00 pm. Four readings each of PARinc and PARt were recorded at different spots of each plot. The proportion of intercepted PAR (PARint) was calculated using the following equation and expressed in percentage (Ahmed et al., 2010):

Light availability $\{$ PARint $(\%)\}=\frac{\text { PARinc- PARt }}{\text { PARinc }} 100$

Whrer, PARinc $=$ Incident PAR, PARt $=$ Transmitted PAR, PARint $=$ Intercepted PAR. 
There was no facility to measure light availability in Burirhat, Rangpur. Data on yield contributing characters of sorghum were taken from randomly selected 5 plants from each plot. Yields of both the crops were taken from whole plot area in both locations. In $1^{\text {st }}$ year, sorghum was harvested on 4 April, 2019 and gardenpea was harvested 2 times on 20 and 28 January, 2019 and in $2^{\text {nd }}$ year, gardenpea was harvested 2 times on 25 and 31 January, 2020 and sorghum was harvested on 14 April, 2020 at Joydebpur. On the other hand, in $1^{\text {st }}$ year, sorghum was harvested on 5 April, 2019 and gardenpea was harvested 2 times on 25 January and 2 February, 2019 and in $2^{\text {nd }}$ year, gardenpea was harvested 2 times on 2 and 10 February, 2019 and sorghum was harvested on 15 April, 2020 at Burirhat. In both locations, SEY was computed by converting yield of intercrops on the basis of prevailing market price of individual crop following the formula by Bandyopadhyay (1984) as given below:

Sorghum equivalent yield $=$ Yis $+($ Yigp $\times$ Pgp $) / P s$

Where, Yis $=$ Yield of intercropped sorghum, Yigp = Yield of intercropped gardenpea,

Ps $=$ Market price of sorghum and Pgp = Market price of gardenpea.

Land equivalent ratio (LER) was obtained according to Willey (1979) as follows:

$$
\text { LER }=\frac{\text { Yield of sorghum as intercrop }}{\text { Yield of sorghum as sole crop }}+\frac{\mathrm{ld} \text { of gardenpea as intercrop }}{\text { :ld of gardenpea as sole crop }}
$$

Collected data of both the crops were analyzed statistically and the means were adjudged using $\operatorname{LSD}_{(0.05)}$ test. Economic analysis was also done considering local market price of harvested crops.

\section{Results and Discussion}

\section{Light availability}

Availability of light on sorghum and gardenpea in intercropping was not markedly affected with each other in both years. Because gardenpea was harvested at 55-60 DAS. At that time sorghum canopy could not produced much shade which might affect gardenpea. Irrespective of treatments, availability of light on gardenpea canopy was almost $100 \%$ at earlier growth stage, 30 DAS of gardenpea and it decreased with the increase of shade produced by sorghum canopy over the time up to 60 DAS or up to harvest of gardenpea. However, among the intercropping treatments, the higher light availability on gardenpea was observed in $\mathrm{T}_{3}$ treatment followed by $\mathrm{T}_{4}$ throughout the growing period in both the years. The lower light availability on gardenpea was observed in SNR +2 rows gardenpea $\left(\mathrm{T}_{2}\right)$ followed by $\mathrm{T}_{1}$ treatment and the lowest was observed at $60 \mathrm{DAS}$ in the same treatment. Among all treatments, the highest light availability was observed in sole gardenpea $\left(T_{7}\right)$ followed by $T_{3}$ treatment in both the years. Light availability on gardenpea canopy was more in the paired row than normal row of sorghum throughout the growing period and it was higher in 2019-2020 than that of 2018-2019 (Fig.1 a.2018-2019 and b. 2019-2020). It might be due to higher number of tillers hill ${ }^{-1}$ in local variety used in $1^{\text {st }}$ year.
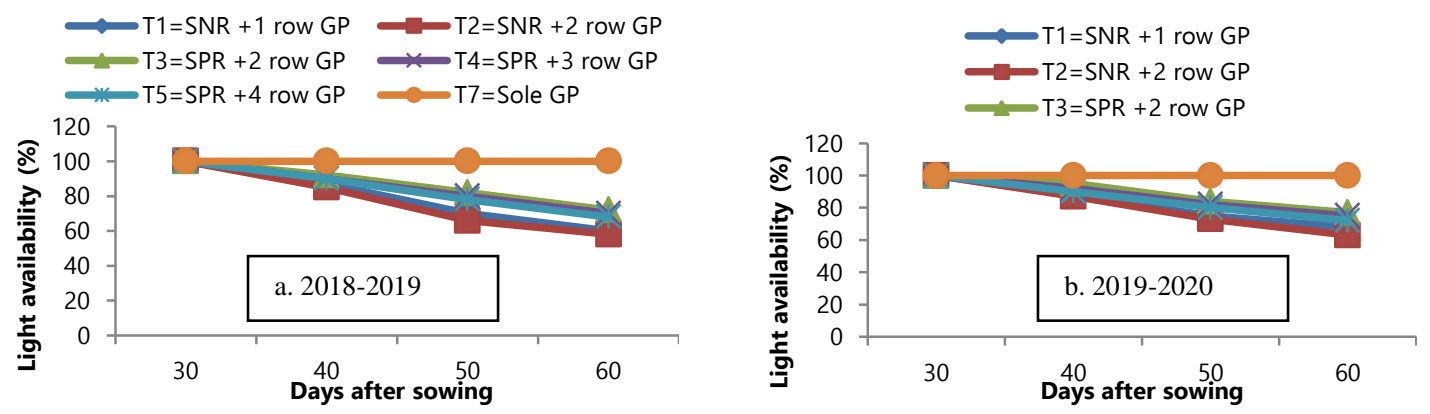

Fig. 1. Light availability on gardenpea canopy in sorghum + gardenpea intercropping systems at Joydebpur (a. 2018-2019 and b. 2019-2020). 


\section{Yield and yield components of sorghum}

Grain yield and yield contributing characters of sorghum at both locations during Rabi of 2018-2019 and 2019-2020 have been presented in Table 1 and Table 2. Plant height, yield contributing characters (number of panicles hill ${ }^{-1}$, panicle length, number of grains panicle ${ }^{-1}, 1000$-grain weight) and grain yield of sorghum were not significantly differed among the treatments in both years in both locations.

\section{At Joydebpur}

The highest grain yield ( $3.87 \mathrm{tha}^{-1}$ in $1^{\text {st }}$ year and $4.41 \mathrm{t} \mathrm{ha}^{-1}$ in $2^{\text {nd }}$ year) were recorded in sole sorghum due to no intercrop competition for growth resources like light, nutrients, moisture and space in sole cropping.

Table 1. Plant height, panicle hill $^{-1}$, panicle length and grains panicle ${ }^{-1}$ of sorghum in sorghum + gardenpea intercropping during Rabi of 2019-2020 (Joydebpur and Burirhat, Rangpur)

\begin{tabular}{|c|c|c|c|c|c|c|c|c|}
\hline \multirow[t]{2}{*}{ Treatments } & \multicolumn{2}{|c|}{ Plant height (cm) } & \multicolumn{2}{|c|}{ Panicles hill $^{-1}$ (no.) } & \multicolumn{2}{|c|}{ Panicle length $(\mathrm{cm})$} & \multicolumn{2}{|c|}{$\begin{array}{c}\text { Grains panicle }^{-1} \\
\text { (no.) }\end{array}$} \\
\hline & $\begin{array}{l}\text { 2018- } \\
2019\end{array}$ & $\begin{array}{l}2019- \\
2020\end{array}$ & $\begin{array}{l}\text { 2018- } \\
2019\end{array}$ & $\begin{array}{l}2019- \\
2020\end{array}$ & $\begin{array}{l}\text { 2018- } \\
2019\end{array}$ & $\begin{array}{l}2019- \\
2020\end{array}$ & $\begin{array}{l}\text { 2018- } \\
2019\end{array}$ & $\begin{array}{l}2019- \\
2020\end{array}$ \\
\hline \multicolumn{9}{|l|}{ Joydebpur } \\
\hline $\mathrm{T}_{1}$ & 185.3 & 134 & 5.3 & 2.1 & 18.40 & 16.6 & 784 & 1541 \\
\hline $\mathrm{T}_{2}$ & 184.0 & 136 & 5.3 & 2.1 & 18.87 & 16.5 & 756 & 1543 \\
\hline $\mathrm{T}_{3}$ & 192.0 & 136 & 5.0 & 2.1 & 18.67 & 16.8 & 723 & 1591 \\
\hline $\mathrm{T}_{4}$ & 186.7 & 137 & 5.3 & 2.1 & 19.13 & 16.6 & 794 & 1597 \\
\hline $\mathrm{T}_{5}$ & 185.7 & 136 & 5.7 & 2.2 & 19.80 & 16.8 & 742 & 1604 \\
\hline $\mathrm{T}_{6}$ & 193.0 & 137 & 5.3 & 2.3 & 19.60 & 17.4 & 814 & 1615 \\
\hline $\operatorname{LSD}_{(0.05)}$ & NS & NS & NS & NS & NS & NS & NS & NS \\
\hline $\mathrm{CV}(\%)$ & 7.80 & 3.82 & 6.05 & 8.63 & 5.70 & 6.88 & 10.37 & 6.13 \\
\hline \multicolumn{9}{|c|}{ Burirhat, Rangpur } \\
\hline $\mathrm{T}_{1}$ & 185.3 & 132 & 6.0 & 1.5 & 18.40 & 17.97 & 788 & 1570 \\
\hline $\mathrm{T}_{2}$ & 187.7 & 135 & 6.0 & 1.0 & 18.87 & 17.83 & 759 & 1530 \\
\hline $\mathrm{T}_{3}$ & 184.0 & 137 & 5.7 & 1.8 & 18.67 & 17.85 & 766 & 1582 \\
\hline $\mathrm{T}_{4}$ & 183.3 & 128 & 5.7 & 1.1 & 19.13 & 18.15 & 798 & 1564 \\
\hline $\mathrm{T}_{5}$ & 187.0 & 129 & 6.3 & 1.3 & 19.80 & 18.39 & 758 & 1574 \\
\hline $\mathrm{T}_{6}$ & 190.3 & 139 & 6.7 & 2.6 & 19.60 & 18.72 & 818 & 1602 \\
\hline $\operatorname{LSD}_{(0.05)}$ & NS & NS & NS & NS & NS & NS & NS & NS \\
\hline CV (\%) & 5.93 & 5.18 & 7.90 & 8.63 & 6.30 & 5.41 & 8.63 & 5.94 \\
\hline
\end{tabular}

This corroborates with the findings of Begum et al. (2016). Among the intercropping system, $\mathrm{T}_{5}$ (SPR +4 rows GP) gave the highest grain yield (3.64 tha ${ }^{-1}$ in $1^{\text {st }}$ year and $4.39 \mathrm{tha}^{-1}$ in $2^{\text {nd }}$ year $)$ followed by $\mathrm{T}_{4}$. The lowest grain yield ( $3.47 \mathrm{t} \mathrm{ha}^{-1}$ in $1^{\text {st }}$ year and $3.90 \mathrm{t} \mathrm{ha}^{-1}$ in $2^{\text {nd }}$ year) was recorded in $\mathrm{SNR}+2$ rows GP $\left(\mathrm{T}_{2}\right)$. However, grain yield of sorghum in different treatments were attributed by the cumulative effect of yield components.

\section{At Burirhat, Rangpur}

The highest grain yield (3.92 $\mathrm{tha}^{-1}$ in $1^{\text {st }}$ year and $4.46 \mathrm{t} \mathrm{ha}^{-1}$ in $2^{\text {nd }}$ year) were recorded in sole sorghum due to no intercrop competition for growth resources like light, nutrients, moisture and space in sole cropping. This corroborates with the findings of Begum et al. (2016). Among the intercropping system, $\mathrm{T}_{5}(\mathrm{SPR}+4$ rows $\mathrm{GP})$ gave the highest grain yield $\left(3.71 \mathrm{tha}^{-1}\right.$ in $1^{\text {st }}$ year and $4.20 \mathrm{tha} \mathrm{ha}^{-1}$ in $2^{\text {nd }}$ year) followed by $\mathrm{T}_{4}$. The lowest grain yield $\left(3.49 \mathrm{t} \mathrm{ha}^{-1}\right.$ in $1^{\text {st }}$ year and $3.83 \mathrm{t} \mathrm{ha}^{-1}$ in $2^{\text {nd }}$ year) was recorded in $\mathrm{SNR}+1$ row GP $\left(\mathrm{T}_{1}\right)$. However, grain yield of sorghum in different treatments were attributed by the cumulative effect of yield components. 
Grain yield of sorghum in $2^{\text {nd }}$ year was higher than that of in $1^{\text {st }}$ year in both locations. It might be due to local variety of sorghum was used in $1^{\text {st }}$ year and in $2^{\text {nd }}$ year, HYV BARI sorghum-1 was used in both locations.

Table 2. 1000-grain weight and grain yield of sorghum in sorghum + gardenpea intercropping during Rabi of 2019-2020 (Joydebpur and Burirhat, Rangpur)

\begin{tabular}{|c|c|c|c|c|c|c|}
\hline \multirow[t]{2}{*}{ Treatments } & \multicolumn{2}{|c|}{$\begin{array}{l}\text { 1000-grain wt. } \\
(\mathrm{g})\end{array}$} & \multicolumn{2}{|c|}{$\begin{array}{c}\text { Grain yield } \\
\left(t \text { ha }^{-1}\right)\end{array}$} & \multicolumn{2}{|c|}{$\begin{array}{c}\text { Yield decrease over sole } \\
\text { sorghum }(\%)\end{array}$} \\
\hline & 2018-2019 & 2019-2020 & 2018-2019 & 2019-2020 & 2018-2019 & 2019-2020 \\
\hline \multicolumn{7}{|l|}{ Joydebpur } \\
\hline $\mathrm{T}_{1}$ & 16.67 & 33.13 & 3.54 & 3.94 & 9 & 11 \\
\hline $\mathrm{T}_{2}$ & 16.93 & 32.13 & 3.47 & 3.90 & 10 & 12 \\
\hline $\mathrm{T}_{3}$ & 16.93 & 33.33 & 3.52 & 3.91 & 9 & 11 \\
\hline $\mathrm{T}_{4}$ & 16.60 & 33.73 & 3.54 & 4.12 & 9 & 7 \\
\hline $\mathrm{T}_{5}$ & 16.67 & 33.80 & 3.64 & 4.39 & 6 & 1 \\
\hline $\mathrm{T}_{6}$ & 17.07 & 33.32 & 3.87 & 4.41 & - & - \\
\hline $\operatorname{LSD}_{(0.05)}$ & NS & NS & NS & NS & - & - \\
\hline $\mathrm{CV}(\%)$ & 5.50 & 5.31 & 5.84 & 9.64 & - & - \\
\hline \multicolumn{7}{|c|}{ Burirhat, Rangpur } \\
\hline $\mathrm{T}_{1}$ & 16.80 & 32.02 & 3.49 & 3.83 & 11 & 14 \\
\hline $\mathrm{T}_{2}$ & 17.07 & 32.35 & 3.65 & 3.98 & 7 & 11 \\
\hline $\mathrm{T}_{3}$ & 16.07 & 31.93 & 3.58 & 4.03 & 9 & 10 \\
\hline $\mathrm{T}_{4}$ & 16.73 & 32.47 & 3.65 & 4.01 & 7 & 10 \\
\hline $\mathrm{T}_{5}$ & 16.93 & 32.56 & 3.71 & 4.20 & 5 & 6 \\
\hline $\mathrm{T}_{6}$ & 17.73 & 33.03 & 3.92 & 4.46 & - & - \\
\hline $\operatorname{LSD}_{(0.05)}$ & NS & NS & NS & NS & - & - \\
\hline $\mathrm{CV}(\%)$ & 4.57 & 6.22 & 5.77 & 7.13 & - & - \\
\hline
\end{tabular}

$\mathrm{T}_{1}=$ Sorghum normal row $(\mathrm{SNR})+1$ row gardenpea $(\mathrm{GP}), \mathrm{T}_{2}=\mathrm{SNR}+2$ rows GP, $\mathrm{T}_{3}=$ Sorghum paired row $(\mathrm{SPR})+2$ rows $\mathrm{GP}, \mathrm{T}_{4}=\mathrm{SPR}+3$ rows $\mathrm{GP}, \mathrm{T}_{5}=\mathrm{SPR}+4$ rows GP, $\mathrm{T}_{6}=$ Sole sorghum $(60 \mathrm{~cm} \times 10 \mathrm{~cm})$ and $\mathrm{T}_{7}=$ Sole $\mathrm{GP}(30 \mathrm{~cm} \times$ $10 \mathrm{~cm})$

\section{Yield of gardenpea}

Yield and yield components of gardenpea in different sorghum + gardenpea intercropping in both the locations (Joydebpur and Burirhat, Rangpur) during Rabi of 2018-2019 and 2019-2020 have been presented in (Table 3). Number of plants $\mathrm{m}^{-2}$ and green pod yield of gardenpea were significantly influenced by different planting systems in both year and in both locations.

\section{At Joydebpur}

The highest number of plants $\mathrm{m}^{-2}$ was observed in sole gardenpea $\left(28 \mathrm{~m}^{-2}\right.$ in $1^{\text {st }}$ year and $\quad 26 \mathrm{~m}^{-2}$ in $2^{\text {nd }}$ year $)$ and the lowest was observed in $T_{1}$ treatment $\left(11 \mathrm{~m}^{-2}\right.$ in $1^{\text {st }}$ year and $10 \mathrm{~m}^{-2}$ in $2^{\text {nd }}$ year $)$ due to variation of planting system. The highest green pod yield $\left(8.84 \mathrm{t} \mathrm{ha}^{-1}\right.$ in $1^{\text {st }}$ year and $8.18 \mathrm{tha}^{-1}$ in $2^{\text {nd }}$ year) was found in sole gardenpea due to higher plant population per unit area. There was no intercrop competition for growth resources in sole cropping of gardenpea. Among the intercrop treatments, the highest green pod yield $\left(7.29 \mathrm{t} \mathrm{ha}^{-1}\right.$ in $1^{\text {st }}$ year and $7.63 \mathrm{t} \mathrm{ha}^{-1}$ in $2^{\text {nd }}$ year) was observed in $\mathrm{T}_{5}$. The lowest green pod yield $\left(3.89 \mathrm{tha}^{-1}\right)$ was observed in $\mathrm{T}_{3}$ in $1^{\text {st }}$ year and in $\mathrm{T}_{1}$ in $2^{\text {nd }}$ year $\left(4.67 \mathrm{tha}^{-1}\right)$ due to the lowest number of plant population of gardenpea per unit area.

\section{At Burirhat}

More or less similar trend was observed in Burirhat. The highest number of plants $\mathrm{m}^{-2}$ was observed in sole gardenpea $\left(30 \mathrm{~m}^{-2}\right.$ in $1^{\text {st }}$ year and $27 \mathrm{~m}^{-2}$ in $2^{\text {nd }}$ year) and the lowest was observed in $\mathrm{T}_{3}$ treatment $\left(12 \mathrm{~m}^{-2}\right.$ in both year) due to variation of planting system. The highest green pod yield $\left(9.95 \mathrm{t} \mathrm{ha}^{-1}\right.$ in $1^{\text {st }}$ year and $8.68 \mathrm{t} \mathrm{ha}^{-1}$ in $2^{\text {nd }}$ year) was found in sole gardenpea due to higher plant population per unit area. There was no intercrop competition for growth resources in sole cropping of gardenpea. Among 
the intercrop treatments, the highest green pod yield $\left(8.35 \mathrm{tha}^{-1}\right.$ in $1^{\text {st }}$ year and $7.57 \mathrm{t} \mathrm{ha}^{-1}$ in $2^{\text {nd }}$ year) was observed in $T_{5}$. The lowest green pod yield $\left(4.68 \mathrm{tha}^{-1}\right)$ was observed in $\mathrm{T}_{3}$ in $1^{\text {st }}$ year and in $\mathrm{T}_{1}$ in $2^{\text {nd }}$ year $\left(5.02 \mathrm{t} \mathrm{ha}^{-1}\right)$ due to the lowest number of plant population of gardenpea per unit area.

Table 3. Plant height, yield and yield components of gardenpea in sorghum + gardenpea intercropping during Rabi of 2019-2020 (Joydebpur and Burirhat, Rangpur)

\begin{tabular}{|c|c|c|c|c|c|c|c|c|c|c|}
\hline \multirow[t]{2}{*}{ Treatments } & \multicolumn{2}{|c|}{ Plant height (cm) } & \multicolumn{2}{|c|}{$\begin{array}{c}\text { Plants m }^{-2} \\
\text { (no.) }\end{array}$} & \multicolumn{2}{|c|}{$\begin{array}{c}\text { Pod plant }^{-1} \\
\text { (no.) }\end{array}$} & \multicolumn{2}{|c|}{$\begin{array}{c}\text { Seed pod }^{-1} \\
\text { (no.) }\end{array}$} & \multicolumn{2}{|c|}{$\begin{array}{c}\text { Green pod yield } \\
\left(\mathrm{t} \mathrm{ha}^{-1}\right)\end{array}$} \\
\hline & $\begin{array}{l}2018- \\
2019 \\
\end{array}$ & $\begin{array}{l}2019- \\
2020\end{array}$ & $\begin{array}{l}2018- \\
2019 \\
\end{array}$ & $\begin{array}{l}2019- \\
2020 \\
\end{array}$ & $\begin{array}{l}2018- \\
2019 \\
\end{array}$ & $\begin{array}{l}2019- \\
2020\end{array}$ & $\begin{array}{l}2018- \\
2019 \\
\end{array}$ & $\begin{array}{l}2019- \\
2020\end{array}$ & $\begin{array}{l}2018- \\
2019 \\
\end{array}$ & $\begin{array}{l}2019- \\
2020 \\
\end{array}$ \\
\hline \multicolumn{11}{|l|}{ Joydebpur } \\
\hline $\mathrm{T}_{1}$ & 50.33 & 48.5 & 12 & 10 & 6.33 & 6.4 & 5.07 & 5.07 & 4.76 & 4.67 \\
\hline $\mathrm{T}_{2}$ & 51.40 & 51.4 & 21 & 23 & 6.27 & 6.4 & 5.13 & 5.13 & 6.44 & 7.62 \\
\hline $\mathrm{T}_{3}$ & 50.87 & 48.5 & 11 & 13 & 7.13 & 7.2 & 5.07 & 5.07 & 3.89 & 4.72 \\
\hline $\mathrm{T}_{4}$ & 51.87 & 50.5 & 14 & 15 & 6.73 & 6.8 & 5.13 & 5.13 & 6.25 & 6.92 \\
\hline $\mathrm{T}_{5}$ & 52.67 & 51.3 & 21 & 23 & 6.53 & 6.6 & 5.20 & 5.20 & 7.29 & 7.63 \\
\hline $\mathrm{T}_{7}$ & 49.47 & 48.4 & 28 & 26 & 7.33 & 7.4 & 6.87 & 6.87 & 8.84 & 8.18 \\
\hline $\operatorname{LSD}_{(0.05)}$ & NS & NS & 4.06 & 5.54 & NS & NS & NS & NS & 1.05 & 2.47 \\
\hline $\mathrm{CV}(\%)$ & 10.20 & 5.94 & 8.35 & 12.20 & 13.30 & 8.77 & 6.67 & 6.67 & 6.60 & 14.42 \\
\hline \multicolumn{11}{|c|}{ Burirhat, Rangpur } \\
\hline $\mathrm{T}_{1}$ & 64.43 & 57.8 & 14 & 14 & 8.1 & 8.20 & 7.90 & 5.67 & 5.80 & 5.15 \\
\hline $\mathrm{T}_{2}$ & 63.63 & 55.7 & 25 & 23 & 8.0 & 7.87 & 7.63 & 5.00 & 7.54 & 6.48 \\
\hline $\mathrm{T}_{3}$ & 64.83 & 59.5 & 12 & 12 & 8.9 & 8.73 & 7.87 & 5.20 & 4.68 & 5.02 \\
\hline $\mathrm{T}_{4}$ & 64.23 & 56.3 & 18 & 16 & 8.5 & 8.07 & 8.07 & 5.13 & 7.25 & 6.62 \\
\hline $\mathrm{T}_{5}$ & 64.43 & 59.4 & 24 & 21 & 8.3 & 8.33 & 8.03 & 5.73 & 8.35 & 7.57 \\
\hline $\mathrm{T}_{7}$ & 61.83 & 58.5 & 30 & 27 & 9.1 & 9.20 & 8.10 & 6.07 & 9.95 & 8.68 \\
\hline$\overline{L S D}_{(0.05)}$ & NS & NS & 4.81 & 6.83 & NS & NS & NS & NS & 0.58 & 0.86 \\
\hline $\mathrm{CV}(\%)$ & 8.90 & 3.06 & 9.09 & 14.01 & 12.67 & 10.68 & 6.89 & 9.93 & 4.39 & 4.59 \\
\hline
\end{tabular}

$\mathrm{T}_{1}=(\mathrm{SNR})+1$ row $\mathrm{GP}, \mathrm{T}_{2}=\mathrm{SNR}+2$ row GP, $\mathrm{T}_{3}=$ Sorghum paired row $(\mathrm{SPR})+2$ row $\mathrm{GP}, \mathrm{T}_{4}=\mathrm{SPR}+3$ row $\mathrm{GP}, \mathrm{T}_{5}=\mathrm{SPR}$ +4 row $\mathrm{GP}, \mathrm{T}_{6}=$ Sole sorghum $(60 \mathrm{~cm} \times 10 \mathrm{~cm})$ and $\mathrm{T}_{7}=$ Sole $\mathrm{GP}(30 \mathrm{~cm} \times 10 \mathrm{~cm})$

\section{Evaluation of intercrop productivity}

Sorghum and gardenpea intercrop productivity was evaluated on the basis of land equivalent ratio and sorghum equivalent yield (Bandyophadhyay, 1984). Land equivalent ratio (LER) and sorghum equivalent yield (SEY) of different treatment in both locations have been presented in Table 4. The LER values were found more than unity in all the intercropping systems indicated that land was more efficiently utilized under intercropping than sole cropping of sorghum and gardenpea.

\section{At Joydebpur}

The LER values in the intercrops ranged from 1.35 to 1.77 in $1^{\text {st }}$ year and 1.46 to 1.93 in $2^{\text {nd }}$ year which indicated that land utilization increased 35 to $77 \%$ in $1^{\text {st }}$ year and 46 to $93 \%$ in $2^{\text {nd }}$ year by intercropping. The highest LER (1.77 and 1.93 in $1^{\text {st }}$ and $2^{\text {nd }}$ year, respectively) was observed in SPR + 4 rows GP $\left(\mathrm{T}_{5}\right)$. SEY of all the intercropping systems was higher than sole sorghum indicating higher productivity of intercropping than sole sorghum. In intercropping, the highest sorghum equivalent yield (10.93 and $12.02 \mathrm{t} \mathrm{ha}^{-1}$ in $1^{\text {st }}$ and $2^{\text {nd }}$ year, respectively) was observed in $\mathrm{T}_{5}$ treatment (SPR +4 rows GP) which was 182 and $173 \%$ higher than sole sorghum in $1^{\text {st }}$ and $2^{\text {nd }}$ year, respectively. The lowest SEY was observed in $\mathrm{T}_{6}$ (sole sorghum) in both years.

\section{At Burirhat}

Similar trend was observed in Burirhat. The LER values in the intercrops ranged from 1.38 to 1.79 in $1^{\text {st }}$ year 1.43 to 1.80 in $2^{\text {nd }}$ year and which indicated that land utilization increased 38 to $79 \%$ in $1^{\text {st }}$ year and 43 to $80 \%$ in $2^{\text {nd }}$ year by intercropping. The highest LER (1.79 and 1.80 in $1^{\text {st }}$ and $2^{\text {nd }}$ year, 
respectively) was observed in SPR +4 rows GP $\left(\mathrm{T}_{5}\right)$. SEY of all the intercropping systems was higher than sole sorghum indicating higher productivity of intercropping than sole sorghum. In intercropping, the highest sorghum equivalent yield (12.06 and $11.77 \mathrm{t} \mathrm{ha}{ }^{-1}$ in $1^{\text {st }}$ and $2^{\text {nd }}$ year, respectively) was observed in $\mathrm{T}_{5}$ treatment (SPR +4 rows GP) which was 208 and $164 \%$ higher than sole sorghum in $1^{\text {st }}$ and $2^{\text {nd }}$ year, respectively. The lowest SEY was observed in $\mathrm{T}_{6}$ (sole sorghum) in both years.

Table 4. Land equivalent ratio and sorghum equivalent yield as influenced by different planting systems in sorghum + gardenpea intercropping during Rabi of 2019-2020 (Joydebpur and Rangpur)

\begin{tabular}{lcccccc}
\hline Treatments & & LER & \multicolumn{2}{c}{ SEY $\left(\mathbf{t ~ h a}^{-1}\right)$} & \multicolumn{2}{c}{$\begin{array}{c}\text { increased of SEY over } \\
\text { sole sorghum }\end{array}$} \\
\cline { 2 - 7 } & $\mathbf{2 0 1 8 - 2 0 1 9}$ & $\mathbf{2 0 1 9 - 2 0 2 0}$ & $\mathbf{2 0 1 8 - 2 0 1 9}$ & $\mathbf{2 0 1 9 - 2 0 2 0}$ & $\mathbf{2 0 1 8 - 2 0 1 9}$ & $\mathbf{2 0 1 9 - 2 0 2 0}$ \\
\hline Joydebpur & & & & & & \\
\hline $\mathrm{T}_{1}$ & 1.44 & 1.46 & 8.30 & 8.61 & 115 & 95 \\
$\mathrm{~T}_{2}$ & 1.64 & 1.82 & 9.91 & 11.52 & 156 & 161 \\
$\mathrm{~T}_{3}$ & 1.35 & 1.46 & 7.41 & 8.63 & 92 & 96 \\
$\mathrm{~T}_{4}$ & 1.62 & 1.78 & 9.79 & 11.04 & 153 & 150 \\
$\mathrm{~T}_{5}$ & 1.77 & 1.93 & 10.93 & 12.02 & 182 & 173 \\
$\mathrm{~T}_{6}$ & 1.00 & 1.00 & 3.87 & 4.41 & - & - \\
$\mathrm{T}_{7}$ & 1.00 & 1.00 & 8.84 & 8.18 & - & - \\
\hline Burirhat & & & & & & \\
\hline $\mathrm{T}_{1}$ & 1.47 & 1.45 & 9.29 & 8.98 & 137 & 101 \\
$\mathrm{~T}_{2}$ & 1.69 & 1.64 & 11.19 & 10.46 & 186 & 135 \\
$\mathrm{~T}_{3}$ & 1.38 & 1.48 & 8.26 & 9.05 & 111 & 103 \\
$\mathrm{~T}_{4}$ & 1.66 & 1.66 & 10.90 & 10.63 & 178 & 138 \\
$\mathrm{~T}_{5}$ & 1.79 & 1.81 & 12.06 & 11.77 & 208 & 164 \\
$\mathrm{~T}_{6}$ & 1.00 & 1.00 & 3.92 & 4.46 & - & - \\
$\mathrm{T}_{7}$ & 1.00 & 1.00 & 9.95 & 8.68 & - & - \\
\hline
\end{tabular}

$\mathrm{T}_{1}=$ Sorghum normal row $(\mathrm{SNR})+1$ row gardenpea $(\mathrm{GP}), \mathrm{T}_{2}=\mathrm{SNR}+2$ rows GP, $\mathrm{T}_{3}=$ Sorghum paired row $(\mathrm{SPR})+2$ rows $\mathrm{GP}, \mathrm{T}_{4}=\mathrm{SPR}+3$ rows $\mathrm{GP}, \mathrm{T}_{5}=\mathrm{SPR}+4$ rows $\mathrm{GP}, \mathrm{T}_{6}=$ Sole sorghum $(60 \mathrm{~cm} \times 10 \mathrm{~cm})$ and $\mathrm{T}_{7}=\mathrm{Sole} \mathrm{GP}(30 \mathrm{~cm} \times$ $10 \mathrm{~cm})$

\section{Economic performance}

Cost and return analysis is an important tool to evaluate the economic feasibility of intercropping system and monetary advantage was evaluated according to Shah et al. (1991). Benefit cost analysis of sorghum + gardenpea intercropping systems in both locations have been presented in Table 5. Gross return and BCR depends on equivalent yield.

\section{At Joydebpur}

Among intercropping treatments, the highest gross return (Tk. $218600 \mathrm{ha}^{-1}$ and Tk. $240400 \mathrm{ha}^{-1}$ in $1^{\text {st }}$ and $2^{\text {nd }}$ year, respectively) was observed in $\mathrm{T}_{5}$ treatment (sorghum paired row +4 rows gardenpea) and it was close to $\mathrm{T}_{2}$ owing to higher SEY in both years. The gross margin also followed the similar trend of gross return. Cost of production differed among the treatments. The highest cost of production was recorded in $\mathrm{T}_{5}$ treatment which was close to $\mathrm{T}_{2}(\mathrm{SNR}+2$ rows GP) due to involvement of higher costs (higher amount of gardenpea seed and labor cost) in both years. Among intercropping treatments, the highest benefit cost ratio (3.04 and 3.34 in $1^{\text {st }}$ and $2^{\text {nd }}$ year, respectively) was obtained from $\mathrm{T}_{5}(\mathrm{SNR}+$ 4 rows GP) treatment. This result has been supported by the findings of Islam et al. (2013).

\section{At Burirhat}

Among intercropping treatments, the highest gross return (Tk. $241200 \mathrm{ha}^{-1}$ and Tk. $235400 \mathrm{ha}^{-1}$ in $1^{\text {st }}$ and $2^{\text {nd }}$ year, respectively) was observed in $\mathrm{T}_{5}$ treatment (sorghum paired row +4 rows gardenpea) and 
it was close to $\mathrm{T}_{2}$ owing to higher SEY in both years. The gross margin also followed the similar trend of gross return.

Table 5. Benefit cost analysis of sorghum + gardenpea intercropping under different planting system during rabi of 2018-2019 and 2019-2020 (Joydebpur and Burirhat, Rangpur)

\begin{tabular}{|c|c|c|c|c|c|c|c|c|}
\hline & \multicolumn{2}{|c|}{$\begin{array}{l}\text { Gross return } \\
(\text { Tk. ha } \\
\text {-1) }\end{array}$} & \multicolumn{2}{|c|}{$\begin{array}{c}\text { Cost of cultivation (Tk. } \\
\mathrm{ha}^{-1} \text { ) }\end{array}$} & \multicolumn{2}{|c|}{$\begin{array}{l}\text { Gross margin } \\
\left(\text { Tk. ha }{ }^{-1}\right)\end{array}$} & \multicolumn{2}{|c|}{ BCR } \\
\hline & 2018-2019 & 2019-2020 & 2018-2019 & 2019-2020 & 2018-2019 & 2019-2020 & 2018-2019 & 2019-2020 \\
\hline \multicolumn{9}{|c|}{ Joydebpur } \\
\hline $\mathrm{T}_{1}$ & 166000 & 172200 & 66000 & 66000 & 100000 & 106200 & 2.52 & 2.61 \\
\hline $\mathrm{T}_{2}$ & 198200 & 230400 & 73500 & 73500 & 124700 & 156900 & 2.70 & 3.13 \\
\hline $\mathrm{T}_{3}$ & 148200 & 172600 & 66000 & 66000 & 82200 & 106600 & 2.25 & 2.62 \\
\hline $\mathrm{T}_{4}$ & 195800 & 220800 & 70500 & 70500 & 125300 & 150300 & 2.78 & 3.13 \\
\hline $\mathrm{T}_{5}$ & 218600 & 240400 & 72000 & 72000 & 146600 & 168400 & 3.04 & 3.34 \\
\hline $\mathrm{T}_{6}$ & 77400 & 88200 & 52500 & 52500 & 24900 & 35700 & 1.47 & 1.68 \\
\hline $\mathrm{T}_{7}$ & 176800 & 163600 & 61500 & 61500 & 115300 & 102100 & 2.87 & 2.66 \\
\hline \multicolumn{9}{|c|}{ Burirhat } \\
\hline $\mathrm{T}_{1}$ & 185800 & 179600 & 66000 & 66000 & 119800 & 113600 & 2.82 & 2.72 \\
\hline $\mathrm{T}_{2}$ & 223800 & 209200 & 73500 & 73500 & 150300 & 135700 & 3.04 & 2.85 \\
\hline $\mathrm{T}_{3}$ & 165200 & 181000 & 66000 & 66000 & 99200 & 115000 & 2.50 & 2.74 \\
\hline $\mathrm{T}_{4}$ & 218000 & 212600 & 70500 & 70500 & 147500 & 142100 & 3.09 & 3.02 \\
\hline $\mathrm{T}_{5}$ & 241200 & 235400 & 72000 & 72000 & 169200 & 163400 & 3.35 & 3.27 \\
\hline $\mathrm{T}_{6}$ & 78400 & 89200 & 52500 & 52500 & 25900 & 36700 & 1.49 & 1.70 \\
\hline $\mathrm{T}_{7}$ & 199000 & 173600 & 61500 & 61500 & 137500 & 112100 & 3.24 & 2.82 \\
\hline
\end{tabular}

$\mathrm{T}_{1}=(\mathrm{SNR})+1$ row GP, $\mathrm{T}_{2}=\mathrm{SNR}+2$ rows GP, $\mathrm{T}_{3}=$ Sorghum paired row $(\mathrm{SPR})+2$ rows $\mathrm{GP}, \mathrm{T}_{4}=\mathrm{SPR}+3$ rows GP, $\mathrm{T}_{5}=$ SPR +4 rows GP, $T_{6}=$ Sole sorghum $(60 \mathrm{~cm} \times 10 \mathrm{~cm})$ and $\mathrm{T}_{7}=$ Sole GP $(30 \mathrm{~cm} \times 10 \mathrm{~cm})$ Market price $\left(\mathrm{Tk} \mathrm{kg}^{-1}\right): \mathrm{Sorghum}$ $=20$, gardenpea $=20$ in both locations

Cost of production differed among the treatments. The highest cost of production was recorded in $\mathrm{T}_{5}$ treatment which was close to $\mathrm{T}_{2}(\mathrm{SNR}+2$ rows GP) due to involvement of higher costs (higher amount of gardenpea seed and labor cost) in both years. Among intercropping treatments, the highest benefit cost ratio (3.35 and 3.27 in $1^{\text {st }}$ and $2^{\text {nd }}$ year, respectively) was obtained from $\mathrm{T}_{5}$ ( $\mathrm{SNR}+4$ rows GP) treatment. This result has been supported by the findings of Islam et al. (2013).

\section{Conclusion}

Result revealed that all the intercropping showed better productivity and profitability than growing sole sorghum. Sorghum paired row +4 rows gardenpea intercropping was found agronomically feasible and economically profitable in Joydebpur and Rangpur.

\section{References}

Ahmed, F., M.N. Islam, M.T. Rahman, M.A. Jahan and M.S.A. Khan. 2010. Leaf area index, radiation interception, dry matter production and grain yield of hybrid maize as influenced by plant spacing. Bangladesh Agron. J. 13(1 \& 2): 51-58.

Bandyopadhyay, S.N. 1984. Nitrogen and water relations in grain sorghum-legume intercropping systems. Ph. D. Dissertation, Indian Agricultural Research Institute, New Delhi.

Begum, A.A., M.S.U. Bhuiya, S.M.A. Hossain, Amina Khatun and S.K. Das. 2016. Effect of planting system of potato and plant density of maize on productivity of potato- hybrid maize intercropping system. Bangladesh J. Agril. Res. 41(3): 397-409.

FRG (Fertilizer Recommendation Guide). 2018. Bangladesh Agricultural Research Council (BARC), Farmgate, Dhaka 1215. 223p. 
Islam, M.N., M. Akhteruzzaman and M.S. Alom. 2013. Split application of inorganic fertilizers in potato (Solanum tuberosum L.)-hybrid maize (Zea mays L.) intercropping system. Bangladesh J. Agril. Res. 38(3): 447-453.

Islam, M.N., M.M. Haque and A. Hamid. 2006. Planting arrangement and population density effects on the physiological attributes and productivity of maize-bushbean intercropping systems. Bangladesh J. Agril. Res. 31(3): 353-364.

Kakraliya, S.K., U. Singh, A. Bohra and K.K. Chaudhary. 2018. Nitrogen and Legumes: A Metaanalysis. In: Legumes for Soil Health and Sustanable Management. 277-314pp. http://researchgate.net/publication/326227137_Nitrogen_and_Legumes_A_Meta-analysis.

Mahfuza, S.N., M.N. Islam, A. Hannan, M. Akhteruzzaman and S. Begum. 2012. Intercropping different vegetables and spices with pointed gourd. J. Expt. Biosci. 3(1): 77-82.

Meena, R.S., R.S.Yadav, H. Meena, S. Kumar, Y.K. Meena and A. Singh 2015. Towards the current need to enhance legume productivity and soil sustainability worldwide: a book review. J Clean Prod. 104: 513-515

Shah, N.H., P.K. Koul, B.A. Khanday and D. Kachrov. 1991. Production potential and monetary advantage index of maize intercropped with different grain legumes. Indian J. Agron. 36(1): 23-28.

Taylor, J., T.J. Schober and S.R. Bean. 2006. Novel food and Work at Sebnie and Merse Mengesha /Arch. Agr. Environ. Sci. 3(2): 180-186.

Thimmaiah, S.K. 2002. Effect of salinity on biochemical composition of sorghum (Sorghum bicolor L.) seeds. Indian J. Agril. Biochem. 15(1-2): 13-15.

Willey, R.W. 1979. Intercropping: its performance and research needs. Part I. Competition and yield advantages. Field Crops Abs. 32: 1-10.

Yan, K., P. Chen, H. Shao, S. Zhao, L. Zhang, G. Xu and J. Sun. 2012. Responses of photosynthesis and photosystem ii to higher temperature and salt stress in sorghum. J. Agron. Crop Sci. 198(3): 218 -225. https://dx.doi.org/10.1111/j.1439-037X.2011.00498.x 